\title{
Rapid visual screening of building for potential ground movement in Kalirejo, Kulonprogo, Yogyakarta
}

\author{
Sely Novita Sari ${ }^{1 *}$, Rizqi Prastowo ${ }^{2}$, Rahmad Junaidi ${ }^{3}$, Amir Machmud ${ }^{4}$ \\ ${ }^{1}$ Department of Civil Engineering, Institut Teknologi Nasional Yogyakarta, DI Yogyakarta 55281, Indonesia \\ ${ }^{2}$ Department of Mining Engineering, Institut Teknologi Nasional Yogyakarta, DI Yogyakarta 55281, Indonesia \\ ${ }^{3}$ Faculty of Science and Technology, Universitas Islam Negeri Sunan Ampel Malang, East Java, Indonesia \\ ${ }^{4}$ Graduate Institute of Environmental Engineering, National Central University, Taoyuan, Taiwan
}

*Corresponding Address: selynovita23@gmail.com

\begin{tabular}{|c|c|}
\hline Article Info & בABSTRACT \\
\hline Article history: & Kalirejo area. The dynamics of land \\
\hline $\begin{array}{l}\text { Received: November } 11^{\text {st }}, 2019 \\
\text { Accepted: April } 18^{\text {th }}, 2020 \\
\text { Published: April } 30^{\text {th }}, 2020\end{array}$ & $\begin{array}{l}\text { movements in the mountains often cause cracks and potentially collapse. } \\
\text { Landslides due to land fractures caused building damage. This study aimed to } \\
\text { analyze the condition of a simple building on the influence of land fracture. } \\
\text { The method used was conducting a field survey of existing buildings in the }\end{array}$ \\
\hline & $\begin{array}{l}\text { Kalirejo area. The data of the surveys were the percentage of building damage } \\
\text { and building categorization. From the results of the analysis, the percentages }\end{array}$ \\
\hline $\begin{array}{l}\text { Buildings; } \\
\text { Evaluation; } \\
\text { Fractures; } \\
\text { Ground Movement; } \\
\text { RVS. }\end{array}$ & $\begin{array}{l}\text { of buildings in the safe category were } 78 \text { buildings or } 54.17 \% \text {, the buildings } \\
\text { of the unsafe category were } 51 \text { buildings or } 35.42 \% \text {, and buildings with the } \\
\text { unsafe category were } 15 \text { buildings out of } 144 \text { surveyed building with the } \\
\text { percentage of } 10.42 \% \text {. Based on the results of the analysis using the Rapid } \\
\text { Visual Screening (RVS) method, } 15 \text { buildings with unsafe conditions need to } \\
\text { be relocated because they do not use the minimum structure required for } \\
\text { simple buildings while the } 51 \text { buildings with unsafe conditions, repairs must } \\
\text { be made to the structure according to the minimum requirements of simple } \\
\text { buildings. }\end{array}$ \\
\hline
\end{tabular}

(C) 2020 Physics Education Department, UIN Raden Intan Lampung, Indonesia.

\section{INTRODUCTION}

Disasters that occur in the near future in Indonesia remind that Indonesia is a country that is very close to earthquakes, landslides (Rajindra et al., 2019), land movements, storms, and various other natural disasters (Wekke et al., 2019). The disaster that occurred was caused by Indonesia's geographical location in the midst of changing natural conditions (Wekke et al., 2019; Rajindra et al., 2019). A landslide is a process of moving the earth down and out of the slope-forming bodies including rocks (Pirttijärvi et al., 2015), soil, artificial fills, or a combination of both that move by falling, rolling (rotating), sliding, spreading, or flowing (Kasayanond et al., 2019).
The landslide incident in February 2018 in Kulon Progo recorded 14 landslide locations, and there were three worst points, namely West Plono, Nglambur, and Trayu located in Samigaluh District. Landslides reoccur and threaten about 30 lives due to continuous rain in March 2018 with a fracture length of 50 meters and a width of 30 meters and a total of 25 meters.

The land use in the Kalirejo, Hargorejo, and surrounding areas consists of $23 \%$ with a slope of $15-30^{\circ}$. Most of the settler areas correspond to slope $42^{\circ}$ with a pattern of surface displacement. The residential area in Kalirejo is above the andesite. In addition to Settlements, there is also an expansion of 
$57 \%$ in the slope $0^{\circ}-15^{\circ}$ (Prastowo et al., 2018)

Rapid visual screening (RVS) is a method of assessing the vulnerability of a building to potential earthquake hazards based on visual observations from the building's exterior, interior if possible so that its implementation is relatively fast (McNeill \& Labson, 1991). Rapid Visual Screening (RVS) can be used for pre-disaster mitigation. Usually, RVS is used to assess buildings in earthquake disasters. In this study, RVS is used to assess buildings in disaster landslide and landslide movements because the assessment of buildings due to landslides has not yet been developed.

Buildings that have the potential for damage and in areas prone to land displacement result in a greater risk of the building being damaged (Harianto et al., 2018). One way to find out the potential damage to a building is to conduct a building evaluation using a simple building evaluation form (typical of a wall) (Nissen, 1986).

The Research about the potential vulnerability of ground movement area at Kalirejo, Kokap, Kulon Progo, Yogyakarta, found a map of the zone vulnerability of ground movement area that shows the zone vulnerability of ground movement (Harianto et al., 2018), a zone of the vulnerability of ground movement, a zone of vulnerability ground movement of low (Prastowo et al., 2019), medium and high (Mariyanto et al., 2018). Continuing this research, a mapping of the potential damage to buildings will be carried out as a result of a simple building evaluation (typical Wall) in the Kalirejo area, Kokap District, KulonProgo Regency, Yogyakarta.

The aforementioned background makes the writer want to analyze the condition of a simple building in the Kalirejo area, KulonProgo, Yogyakarta because the condition of the building that is by the rules will make the building during a land shift due to fractures of the land which is not so significant (Priadi \& Hududillah, 2018). The current condition of the building also makes the building in the realm of safe (Sulaiman et al., 2019), less secure and unsafe. The condition of the building which is called safe has a percentage of $70-100 \%$ condition, the condition of the building which is called unsafe has a percentage of condition 40-69\%, and the condition of the building which is called unsafe as a percentage of the condition of 0-39\% (Rüpke et al., 2006).

The condition of the building can be assessed by conducting a simple building evaluation (Khalil \& Santos, 2014), many ways to evaluate the building either by calculating the structure or just looking at it from the looks (Shiomi \& Park, 2008). In this study, the analysis of the condition of the building is evaluated by looking at and recording the condition of a simple house with a simple building evaluation form (typical of the wall) (Kim \& Lee, 2007). From this form, we know the condition of existing buildings. There are 40 questions from 11 categories, which are the minimum standards for good buildings.

The formulation of the problem of this study is how to classify simple house buildings due to the potential of the Kalirejo regional land movement, KulonProgo, Yogyakarta, so that from the formulation of the problem, the purpose of this study is to classify simple house buildings due to the potential of the Kalirejo regional land movement, KulonProgo, Yogyakarta.

\section{METHODS}

Rapid Visual Screening (RVS) is a method for facilitating, inventorying, and classifying buildings that are approved to be prone to collapse in earthquake-prone areas. Fast Visual Screening was formulated in FEMA 154 (Lizundia et al., 2015).

FEMA 154 is a Rapid Visual Screening (RVS) method in buildings, so Rapid Visual Screening (RVS) is developed in simple buildings in earthquake-prone areas adapted to simple buildings in Indonesia (Satyarno, 2013) 
Rapid Visual Screening (RVS) in simple buildings in areas prone to ground movement does not yet exist, so this study still uses rapid visual screening in earthquake-prone areas, it is hoped that from this study Rapid Visual Screening (RVS) specifically for areas prone to ground movement. However, in this study, the RVS method is used in areas prone to ground movement (McNeill \& Labson, 1991).

The first step taken was conducting a field survey by looking at existing buildings and adjusting them to a simple building valuation form (Hadibarata \& Rubiyatno, 2019). A simple building form contains the parts of a building that must be owned by a building to make the building structurally strong (Irsadi et al., 2019). On a simple building form, only check the "Yes" column if the building part is following the form or column "No" if the building part does not exist as in the form of the building has a part that matches the form, but the size does not match then the bias can be filled at column "Less."

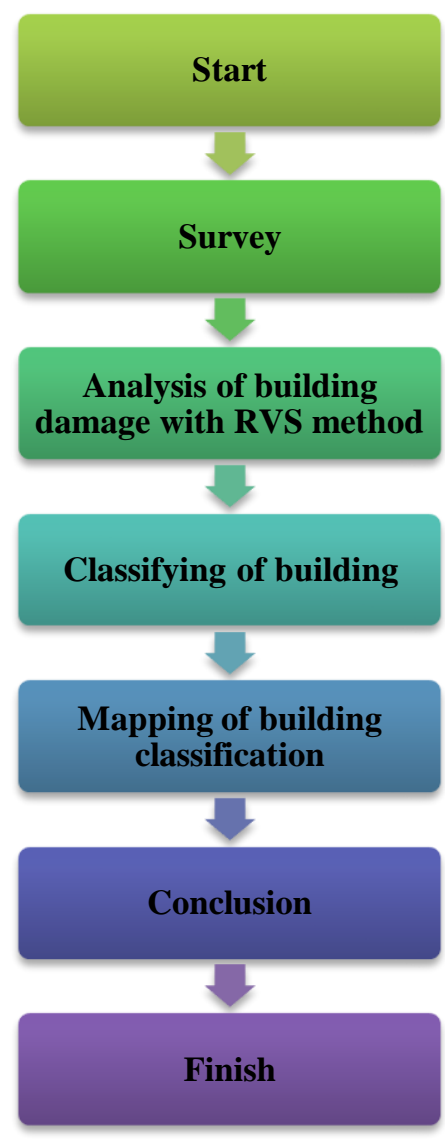

Figure 1. Research Flowchart
After the field survey was carried out, the condition of the existing buildings in the Kalirejo area was obtained, an analysis of building damage was carried out following the filling of simple building forms which were carried out at the time of the field survey (Taruna \& Banyunegoro, 2018). How to analyze it by counting the answer "Yes" multiplied by the value of 1.0 and the answer "Less" multiplied by the value of 0.5. The value of the answer "Yes" and "less" is added divided by 40 (the number of building components simply) multiplied by $100 \%$, then the percentage of simple buildings is obtained according to the simple building assessment form.

After getting a simple percentage of building damage from the analysis of existing forms, it can be classified into three categories of conditions, namely safe percentage $>70 \%$, less safe $40-69 \%$, unsafe $<40 \%$ (Nakajima \& Hasegawa, 2007). Percentage values can also be made on a condition index scale, and their handling measures can be seen in table 1. From these percentages, it can be seen the condition of simple buildings to the influence of the Kalirejo regional land fracture, KulonProgo, Yogyakarta.

\section{RESULTS AND DISCUSSION}

The field survey was conducted in the Kalirejo area, where potential land fractures are following previous research, which obtained the coordinates and the potential land fracture area. The 146 buildings in the existing condition survey were randomly assessed according to a simple building form, with 40 questions of the condition of the buildings (Saehana et al., 2019). The condition of the existing buildings surveyed looks like figure 1 . The field survey is done by going to the house one by one and then matching with the contents of the existing forms, is the building part of the building mentioned formatted then checked in the column "Yes" but if the form is not in the existing building then check the column "No," if the building is following the form, 
but the size is different then check the column "less" (Bemmelen, 1994) and write what the shortcomings are seen in Figure 2.

The survey was carried out following the agreed coordinates with the reference coordinates using a map of potential building strength in the Kalirejo area, as shown in Figure 3. The surveyor started building appraisal by filling out a simple building appraisal form following the coordinates agreed upon previously (Sjaifuddin et al., 2019). How to analyze it by looking at the answer Yes with a value of 1, the answer Less with a value of 0.5 , and the answer is not the value of 0 .

It can be taken as an example on form 1 coded B11-17 in figure 2, from 40 answer questions Yes, which means there are 34 answers in the building, one answer is lacking answers, and no answers are five answers. Analyzed with all 34 answers multiplied by the numbers 1 and 1 , the answer is less multiplied by the number 0.5 .
The sum result was 34.5. To get a building score, the total value of 34.5 divided by 40 multiplied by $100 \%$. Building score results obtained 86.25. How many questions were asked Yes times the value of 1 and more answers less than the value of 0.5. All previous product results are added together to get a total value. To get a Building Score obtained by the formula. Build Score $=$ total score / 40 x $100 \%$.

The build score will be obtained in the form of a percentage of the building conditions. The score obtained will participate in building the score WHICH will be divided into three categorization zones, namely the safe categorization zones for safe building indexes with a percentage of 70$100 \%$, unsafe categorization for building index needs unsafe with a percentage of 40$69 \%$ and unsafe categorization for the unsafe building index conditions with a percentage of $0-39 \%$. In form 1 above, the building value is 86.25 and categorized as safe.

Table 1. Condition Index Scale

\begin{tabular}{ccccc}
\hline Zone & $\begin{array}{c}\text { Condition } \\
\text { Index }\end{array}$ & $\begin{array}{c}\text { Condition } \\
\text { Description }\end{array}$ & Handling Measures & $\begin{array}{c}\text { Building } \\
\text { Categorization }\end{array}$ \\
\hline 1 & $70-100$ & Well & Immediate action is still not needed & Secure \\
2 & $40-69$ & Intermediate & $\begin{array}{c}\text { It is necessary to make an alternative } \\
\text { economic analysis of improvements to } \\
\text { determine the appropriate action } \\
\text { A detailed evaluation is needed to } \\
\text { determine repair, rehabilitation and } \\
\text { reconstruction actions, in addition to } \\
\text { evaluating the safety }\end{array}$ & Unsafe \\
Source: (Smith, 2019) & Bad & & & Not safe \\
\hline
\end{tabular}

Table 2. Results of Kalirejo Regional Building Condition Analysis

\section{Building Categorization}

\begin{tabular}{cccc}
\hline Safe & $70-100$ & 54,17 & Green \\
Unsafe & $40-69$ & 35,42 & Yellow \\
Not Safe & $0-39$ & 10,42 & Red \\
\hline
\end{tabular}

The Color of the

Index Conditions $\quad$ Percentage (\%) Building Category

simple buildings in the four hamlets in the Kalirejo area. Building conditions are obtained by following the conditions index scale according to table 1 and giving color to each building category. Green color for safe building conditions with building conditions 
index value is $70-100 \%$, yellow for unsafe building conditions with building condition index values $40-69 \%$, and red for unsafe building conditions with building condition index values 0-39\%. Building classification in the form of color can be seen in figure 3 .

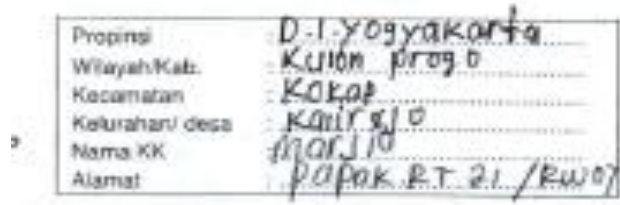

Petunjuk Pengisian : Beri tanda (V) pada kotak yang sesuai

\begin{tabular}{|c|c|c|c|c|c|}
\hline 140 & & PENGAMATAN & $r /$ & TIDAK. & KUFANB \\
\hline A & GAMEAR RENCANA & 1. Perrbengonen berdesarkan gacrear rencies & D & $\underline{\nabla}$ & \\
\hline \multirow{2}{*}{ e } & \multirow{2}{*}{ Denvant } & 2 Denathemetris & B & 口 & \\
\hline & & 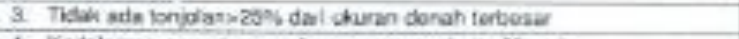 & 무 & S & \\
\hline \multirow{5}{*}{ c } & \multirow{5}{*}{ RONDASI } & 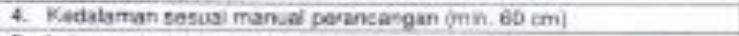 & E & 도 & $30 \mathrm{Cm}$ \\
\hline & & 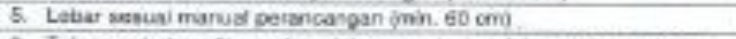 & (t) & D & \\
\hline & & 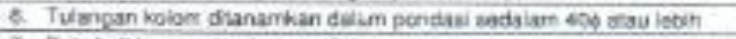 & 由 & ㅁ & \\
\hline & & 7. Bon kall keras atau batu putn keras & $\mathbb{2}$ & D & \\
\hline & & 8. Campuran mertec urthe ssenei 1 pe; 4 per & 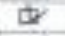 & 口 & \\
\hline \multirow{6}{*}{ D } & \multirow{6}{*}{ SLOOF } & 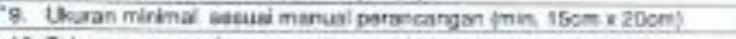 & Wris & 口 & \\
\hline & & 10. Tulangan martaniang seowe merual perancangan imin \&siof & 由 & 모 & \\
\hline & & 11. Tulangas bapel ensuai manual porancenpan imin ef-160) & E & 口 & \\
\hline & & 12. Ads anghut ke torctssi & 8 & a & \\
\hline & & 13. Aowk ah bulen sool bsk ifidsk koroposi & to & $\square$ & \\
\hline & & 14. Cimperien belon 1 pe : 2 per: 3 kd & D & 口 & \\
\hline \multirow{5}{*}{$\mathbf{E}$} & \multirow{5}{*}{ KoLOA } & 15. Ukuran minimal cosuai mavued poraneangati imin. $15 \mathrm{~cm} \times 15 \mathrm{~cm} 0$ & tr & 口 & \\
\hline & & 16. Tuavgen memaneng sesuai maruet perenctongan imn 40100 & to & a & \\
\hline & & 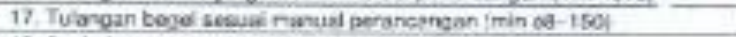 & $\approx$ & 口 & \\
\hline & & 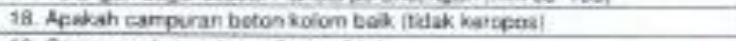 & te & 드 & st \\
\hline & & 19 Carrouran betos 1 pe : 2 par : 3 wal & 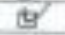 & E & \\
\hline \multirow{3}{*}{$F$} & \multirow{3}{*}{ Dbvative } & 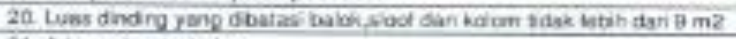 & का & E. & \\
\hline & & 21. Acts enpleir ke kolom & ty & ㅁ & \\
\hline & & 22. Campuran mentar urtibi stonai $1 \mathrm{pe}$ : $4 \mathrm{per}$ & Q & ㅁ & \\
\hline \multirow{5}{*}{ a } & \multirow{5}{*}{ FENG BALX } & 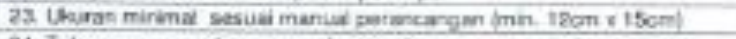 & 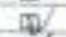 & 므 & \\
\hline & & 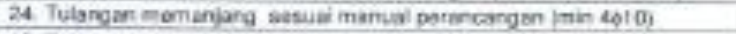 & 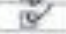 & 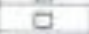 & \\
\hline & & 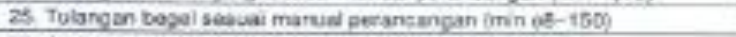 & tor & a & \\
\hline & & 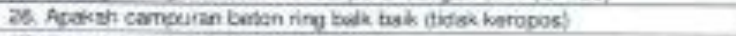 & E! & $\square$ & \\
\hline & & 27. Cancuran teken 1 pe: 2 ber : $3 \mathrm{kt}$ & $\pi$ & (7) & \\
\hline$H$ & $\begin{array}{l}\text { DETAL TLLANGAN } \\
\text { PADA PERTEMUAN } \\
\text { WJUNS BALOK DAN } \\
\text { WOLCM }\end{array}$ & 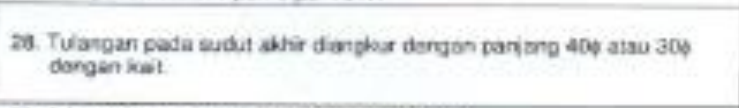 & \pm & $\square$ & \\
\hline 1 & BAMELIACAN & 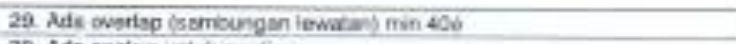 & 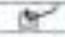 & 무 & \\
\hline \multirow{6}{*}{ 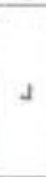 } & \multirow{6}{*}{$\begin{array}{l}\text { GUNAING-GUNSUNG } \\
\text { ideri betory }\end{array}$} & 30. Adn angker untik gonting & W & D & \\
\hline & & 31. Apgkah calfperan baton busok minirg bak (sdak kevoposi & Q & 므. & \\
\hline & & 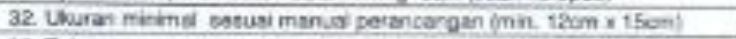 & {$[5$} & $\mathrm{m}$ & \\
\hline & & 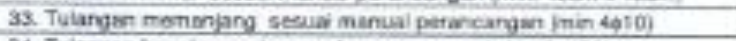 & tri & II & \\
\hline & & 34 Tulargan beve seszai manual perancangan imin os - $155 \%$ & to & 무 & \\
\hline & & 35. Mba iewan argn & 8 & I & \\
\hline \multirow{5}{*}{$\mathrm{x}$} & \multirow{5}{*}{$\begin{array}{l}\text { kUba+ouaA } \\
\text { (tori kaypl) }\end{array}$} & 38. Uhirar kayu minmal 6 on $x 12$ om & 판 & a & \\
\hline & & 37. Sartianzan d beri plat boge & 3 & 口 & \\
\hline & & 38. Ads kestas angin & 무 & $g$ & \\
\hline & & 3e. Nds onpoir poda dudukamya & 므 & D & \\
\hline & & An Krace berwama oclan & $\infty$ & D & \\
\hline
\end{tabular}

Pada kolom kurang dapat dilisi Vdan keteranpan jika kondisinva ada ietapi kurang dani persyaratan mònimum, Jika tidak ta'u berarti "TIOAK".

Jumlah jawaban "YA"

Jumlah jarwaban "KURANG"

Jusnlah nilai

Skor Baneunan $=$ jumlah nilai/40 $\times 100 \%$

$=34 \times 1.0=34$

$=.1 . \times 0.5=0.5$

$=34.5$

- $86.25 \%$

Catatan: jika suatu rumah tidak mempunyai gunung gunung atau kuda-kuda maka jumlah pervyebut di atas tidak 40 tetapi disesuaikan dengan jumlah total pertanyaan rang dapat diisi

\begin{tabular}{|c|c|c|}
\hline Veldati & Parikikperribuat namah & Powasent Evaluae \\
\hline Nama Lesovap & MarJio & Korniausan \\
\hline Tanda Tangan & & \\
\hline Tgt: & & \\
\hline
\end{tabular}

Figure 2. Form of Simple Building Evaluation (typical Wall) 


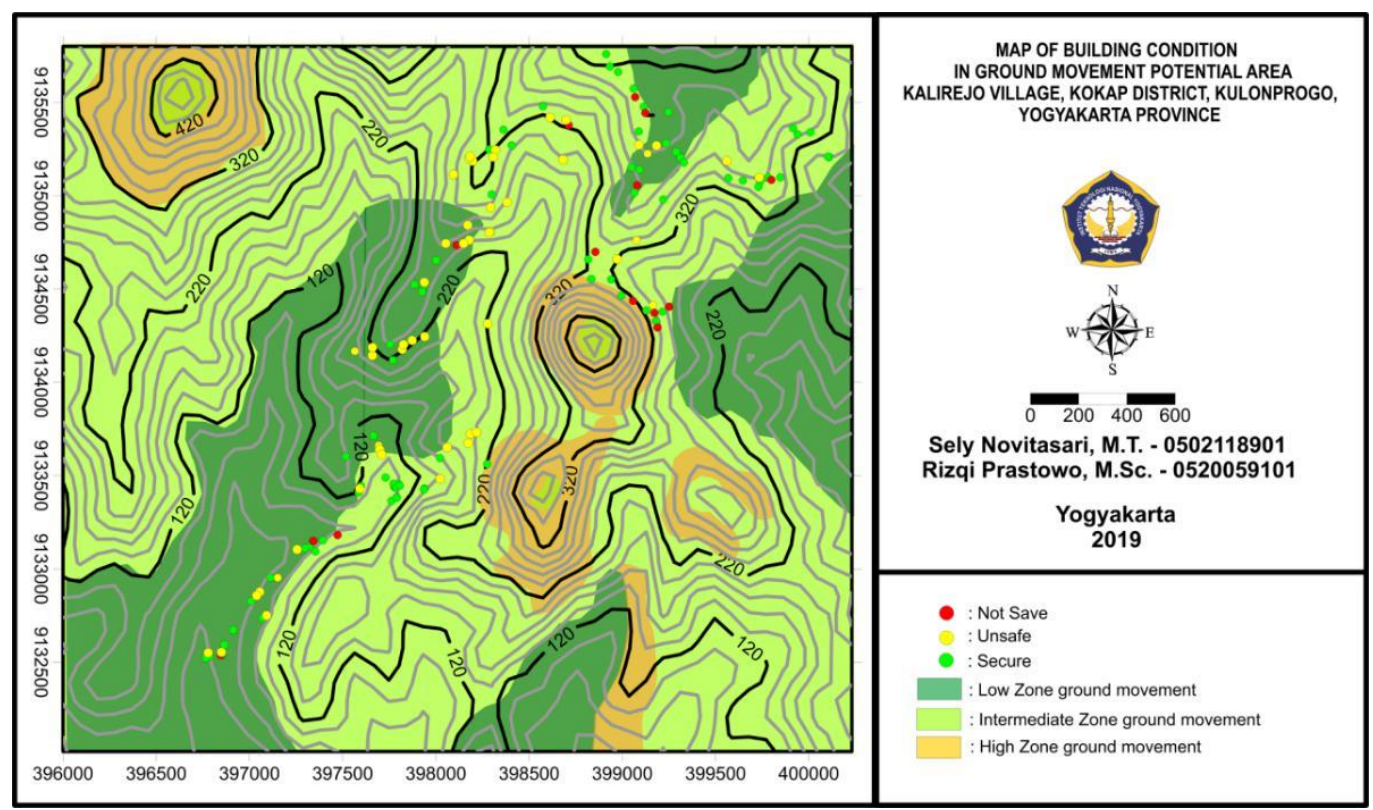

Figure 3. Map of Building Condition of Sample Site at Kokap District, Yogyakarta, Indonesia

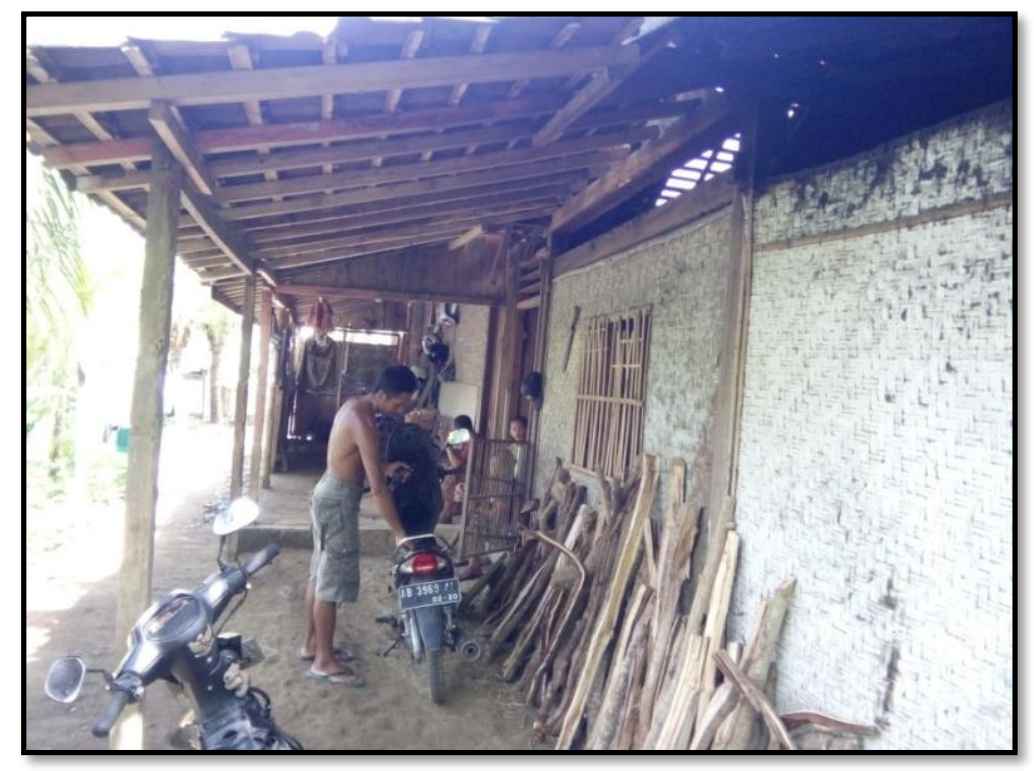

Figure 4. Existing Building

\section{CONCLUSION AND SUGGESTION}

Based on the results of research, the percentage of building conditions and building condition categories obtained the percentage of safe buildings are 78 buildings or $54.17 \%$, buildings in the less secure categories are 51 buildings or $35.42 \%$, and buildings with unsafe categories are 15 buildings out of 144 surveyed buildings with a percentage of $10.42 \%$. There are about
$10.42 \%$ of buildings that have to be considered because of the insufficient building conditions, resilience, and in areas prone to landslides. It is recommended to make a map of the distribution of potential damage to buildings with a map of the potential for existing land fractures so that it can be input for local governments and communities to conduct pre-disaster mitigation. 


\section{ACKNOWLEDGMENT}

Thank you for Ristekdikti for the funding on Hibah Dosen Pemula with contract number 11/SP2H/LT/DPRM/2019; B/ 1435.24/ L5/ RA.00/ 2019; 03.b/ ITNY/ LPPM/ Pen.DPRM/ IV/ 2019.

\section{AUTHOR CONTRIBUTIONS}

All authors were involved in writing manuscript. SN and RP collected and analysed data. RJ and RP writing result and discussion, AM reviewing literature.

\section{REFERENCES}

Bemmelen, R. W. V., (1994). General geology of Indonesia and adjacent archipelagoes. In The geology of Indonesia (2nd ed., p. 732). Nijhoff.

Hadibarata, T., \& Rubiyatno, R. (2019). Active learning strategies in environmental engineering course: A case study in Curtin University Malaysia. Jurnal Pendidikan IPA Indonesia, $\quad 8(4), \quad 456-463$. https://doi.org/10.15294/jpii.v8i4.1916 9

Harianto, H., Kushadiwijayanto, A. A., \& Apriansyah, A. (2018). Physical oceanography condition in Eastern Karimata Strait: Pasir mayang beach West Kalimantan. Jurnal Penelitian Fisika Dan Aplikasinya (JPFA), 8(1), 51.

https://doi.org/10.26740/jpfa.v8n1.p5160

Irsadi, A., Anggoro, S., Soeprobowati, T. R., Helmi, M., \& Khair, A. S. E. (2019). Shoreline and mangrove analysis along semarang-demak, Indonesia for sustainable environmental management. Jurnal Pendidikan IPA Indonesia, $\quad 8(1), \quad 1-11$. https://doi.org/10.15294/jpii.v8i1.1789 2

Kasayanond, A., Umam, R., \& Jermsittiparsert, K. (2019). Environmental sustainability and its growth in Malaysia by elaborating the green economy and environmental efficiency. International Journal of Energy Economics and Policy, 9(5), 465-473.

https://doi.org/https://doi.org/10.32479/ ijeep.8310

Khalil, M. A., \& Santos, F. M. (2014). On the depth to anomaly estimation using Karous and Hjelt filter in VLF-EM data. Arabian Journal of Geosciences, 7(10), 4355-4359.

https://doi.org/10.1007/s12517-0131110-3

Kim, H. C., \& Lee, Y. (2007). Heat flow in the Republic of Korea. Journal of Geophysical Research: Solid Earth, 112(5). https://doi.org/10.1029/2006JB004266 Lizundia, B., Durphy, S., Griffin, M., Holmes, W., Hortacsu, A., Kehoe, B., ... Welliver, B. (2015). Update of FEMA P-154: Rapid visual screening for potential seismic hazards. In Improving the Seismic Performance of Existing Buildings and Other Structures 2015 (pp. 775-786).

Mariyanto, M., Bahri, A. S., Utama, W., Lestari, W., Silvia, L., Lestyowati, T., Anwar, M. K., Ariffiyanto, W., Hibatullah, A. I., \& Amir, M. F. (2018). Relation between transport distance with frequency-dependent volume magnetic susceptibility in Surabaya river sediments. Jurnal Penelitian Fisika Dan Aplikasinya (JPFA), 8(1), 33.

https://doi.org/10.26740/jpfa.v8n1.p3341

McNeill J. D. and Labson V. F. (1991). Electromagnetic methods in applied geophysics. in Misac N. Nabighian (Ed.), Geological mapping using VLF radio fields. In: Nabighian $M N$ (ed) Electromagnetic methods in applied geophysics II (2nd ed., Vol. 2). Society of Exploration Geophysicists.

Nakajima, J., \& Hasegawa, A. (2007). Subduction of the Philippine sea plate beneath southwestern Japan: Slab geometry and its relationship to arc 
magmatism. Journal of Geophysical Research: Solid Earth, 112(8), 1-18. https://doi.org/10.1029/2006JB004770

Nissen, J. (1986). Geophysical prospecting. Geophysical Prospecting, 34(7), 10991110.

Pirttijärvi, M., Zaher, M. A., \& Korja, T. (2015). Combined inversion of airborne electromagneticand static magnetic field data. Geophysica, 50(2), 65-87. https://doi.org/10.13140/RG.2.1.1747.0 486

Prastowo, R., Huda, S., Umam, R., Jermsittiparsert, K., Prasetiyo, A. E., Tortop, H. S., \& Syazali, M. (2019). Academic achievement and conceptual understanding of electrodynamics: Applications Geoelectric using cooperative learning model. Jurnal Ilmiah Pendidikan Fisika Al-Biruni, 8(2), 165-175. https://doi.org/10.24042/jipfalbiruni.v0 i0.4614

Prastowo, R., Trianda, O., \& Novitasari, S. (2018). Identifikasi kerentanan gerakan tanah berdasarkan data geologi daerah Kalirejo, kecamatan Kokap, kabupaten Kulonprogo,. Kurvatek, 03(2), 31-40.

Priadi, R., \& Hududillah, T. H. (2018). Risk level analysis of lightning strike with simple additive weighting method in gowa region. Jurnal Penelitian Fisika Dan Aplikasinya (JPFA), 8(1), 17. https://doi.org/10.26740/jpfa.v8n1.p1724

Rajindra, R., Suardi, I., Sabara, Z., Pushpalal, D., Samad, M. A., Yani, A., \& Umam, R. (2019). Diversity, resilience, and tragedy: Three disasters in Palu of Indonesia. International Journal of Innovation, Creativity and Change, 5(2), 1592-1607.

Rüpke, L., Phipps Morgan, J., \& Dixon, J. E. (2006). Implications of subduction rehydration for earth's deep water cycle. Geophysical Monograph Series, 168, 263. https://doi.org/10.1029/168GM20

Satyarno, I. (2013). Assessment of the 2004/2011 earthquakes and tsunamis in
Indonesia and Japan: Lesson Learnt and Way Forward. In F. Wang, M. Miyajima, T. Li, W. Shan, \& T. F. Fathani (Eds.), Progress of GeoDisaster Mitigation Technology in Asia (pp. 277-292). Berlin, Heidelberg: Springer Berlin Heidelberg. https://doi.org/10.1007/978-3-64229107-4_14

Saehana, S., Ali, M., \& Supriyatman, S. (2019). Thermal expansion and hydrostatic pressure experiment using common materials for supporting science education a rural area at central Sulawesi, Indonesia. Jurnal Pendidikan IPA Indonesia, 8(2), 241-246. https://doi.org/10.15294/jpii.v8i2.1840 3

Shiomi, K., \& Park, J. (2008). Structural features of the subducting slab beneath the Kii Peninsula, central Japan: Seismic evidence of slab segmentation, dehydration, and anisotropy. Journal of Geophysical Research: Solid Earth, 113(10), 1-13. https://doi.org/10.1029/2007JB005535

Sjaifuddin, S., Hidayat, S., Fathurrohman, M., Ardie, R., \& El Islami, R. A. Z. (2019). The development of food security behavior model through environmental-based learning: A system dynamics approach. Jurnal Pendidikan IPA Indonesia, 8(2), 230240.

https://doi.org/10.15294/jpii.v8i2.1886 1

Smith, W. (2019). The role of environment clubs in promoting ecocentrism in secondary schools : Student identity and relationship to the earth. The Journal of Environmental Education, 8964. https://doi.org/10.1080/00958964.2018. 1499603

Sulaiman, B., Bambang, A. N., Purnaweni, H., Lutfi, M., \& Mohammed, E. M. A. (2019). Coastal community perception of mangroves in Suli subdistrict, Luwu. Jurnal Pendidikan IPA Indonesia, 8(4), 561-569. 
https://doi.org/10.15294/jpii.v8i4.2139 6

Taruna, R. M., \& Banyunegoro, V. H. (2018). Earthquake relocation using double difference method for $2 \mathrm{~d}$ modelling of subducting slab and back arc thrust in West Nusa Tenggara. Jurnal Penelitian Fisika Dan Aplikasinya (JPFA), 8(2), 132. https://doi.org/10.26740/jpfa.v8n2.p13 2-143

Wekke, I. S., Rajindra, R., Pushpalal, D.,
Samad, M. A., Yani, A., \& Umam, R. (2019). Educational institution on responding disasters in Palu of Indonesia. INA-Rxiv Papers. https://doi.org/10.31227/osf.io/drc8q Wekke, I. S., Sabara, Z., Samad, M. A., Yani, A., \& Umam, R. (2019). Earthquake, tsunami, and society cooperation : Early findings In Palu Post of Indonesia Disaster. INA-Rxiv Papers. https://doi.org/10.31227/osf.io/xmcyn 